\title{
Lupus vulgaris in a mother and child
}

\author{
Khushboo Arora, Anmol Batra, Aditi Dhanta, Neirita Hazarika
}

Department of Dermatology, Venereology \& Leprosy, All India Institute of Medical Sciences, Rishikesh, Uttarakhand, India

\section{Correspondence to Dr Neirita Hazarika; neiritahazarika@yahoo.com}

Accepted 26 February 2021

\section{DESCRIPTION}

A 32-year-old woman presented to dermatology OPD with asymptomatic reddish lesions over left cheek and lower lip. She brought her 6-year old boy with similar lesions between left eye and nose. The lesions were present for 8 months in both mother and son and were increasing in size. There was no history of preceding trauma to the lesions. There were no systemic complaints in both mother and child. On cutaneous examination of the mother, there was a single well-defined $1 \times 1 \mathrm{~cm}$, erythematous, soft and non-tender nodule, present over left cheek along with an illdefined, erythematous, oedematous, scaly plaque over lower lip (figure 1A,B). The boy had two, well-defined, erythematous, indurated plaques, one with size $2.5 \times 2 \mathrm{~cm}$, with slight scaling and crusting, present on left root of nose with encroachment towards the medial canthus and other of size $1 \times 1 \mathrm{~cm}$, over the left mid-mandible (figure 1C,D). There was no sensory loss over the lesion. On the basis of clinical history and examination differential diagnosis of borderline tuberculoid Hansen's disease, lupus vulgaris (LV), cutaneous leishmaniasis and sarcoidosis

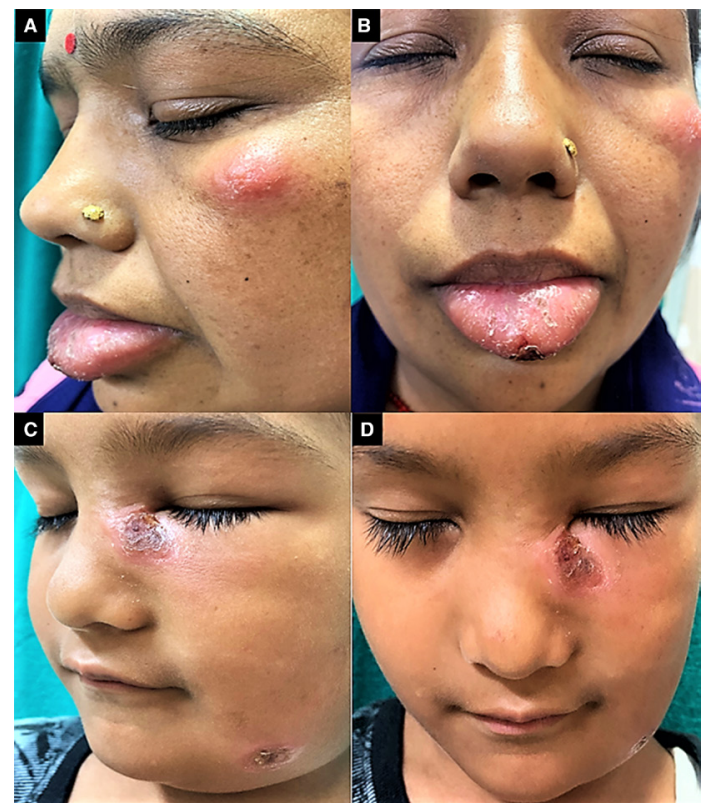

Figure 1 (A, B) Single, well-defined, $1 \times 1 \mathrm{~cm}$, erythematous, soft, non-tender nodule over left cheek along with ill-defined, erythematous, oedematous, scaly plaque over lower lip, in the mother. (C, D) Well-defined, erythematous, indurated plaques, one with size $2.5 \times 2 \mathrm{~cm}$, with slight scaling and crusting, present on left root of nose with encroachment towards the medial canthus and other of size $1 \times 1 \mathrm{~cm}$, over the left mid-mandible, in the son. were kept. Histopathological examination of skin biopsy specimen from both patient revealed epidermal atrophy with lichenoid damage, dermis showed top heavy, granulomatous infiltrate with multiple well-formed epitheloid granulomas without central caseation necrosis (figure 2A) and a few multinucleate Langhans giant cells (figure 2B) suggestive of lichenoid granulomatous reaction pattern compatible with diagnosis of LV. Stain for acid-fast bacillus was negative. Mantoux test of mother showed induration of $20 \mathrm{~cm}$. The patients were counselled and antitubercular treatment (ATT) was started for both of them which resulted in resolution of the lesions in next 3 months.

Cutaneous tuberculosis (TB) constitutes around $1.5 \%$ cases of extra-pulmonary $\mathrm{TB}^{1}{ }^{1}$ Mycobacterium tuberculosis, Mycobacterium bovis and attenuated bacille Calmette-Guerin organism can cause all forms of cutaneous TB. ${ }^{2} \mathrm{LV}$ is a chronic, progressive, post-primary, paucibacillary form of cutaneous $\mathrm{TB}$, occurring in a person with moderate or high degree of immunity. ${ }^{3}$ It arises either endogenously from an underlying focus of TB or from exogenous inoculation. ${ }^{4}$ In India, buttocks and extremities are commonly affected unlike facial involvement in the West. ${ }^{5}$ It starts as brownish to red, soft, solitary plaque, having centrifugal growth. Diascopy reveals apple jelly nodules. Various clinical forms include papular, nodular, plaque, ulcerative, vegetative, hypertrophic, atrophic, tumour like and mutilating type. ${ }^{13}$ Dermoscopy of LV reveals linear telangiectasia on a yellowish golden background with whitish reticular streaks. ${ }^{6}$ The tuberculin skin test is usually strongly positive as seen in our case . Bacterial culture results may be negative. ${ }^{2}$ Histopathology as described in present case is confirmative.

The most likely differentials are leprosy and sarcoidosis. The nodules of leprosy are firmer, and the nodules of sarcoidosis resemble grains of sand rather than 'apple jelly'. Complications include scarring, contractures and tissue destruction. In about $8 \%$ of patients, squamous cell and basal cell carcinomas or sarcomas can occur insidiously. ${ }^{3}$

Treatment involves standard short-course chemotherapy, four ATT drugs for the first 2 months (isoniazid, rifampicin and pyrazinamide), followed by isoniazid and rifampicin for 4 months. $^{7}$

According to a study by Pai et al, there were 14 cases of LV collected over 5 years in a tertiary healthcare centre in India and only 1 case had positive family history. ${ }^{8}$ Our case was unique in that two members of a family (mother and child) had LV simultaneously, which is quite interesting and rare. 


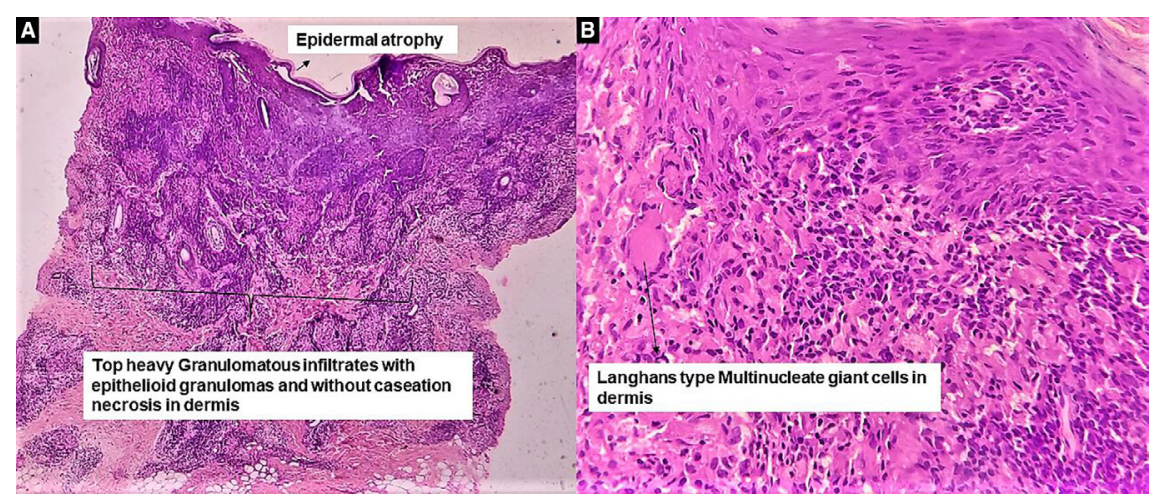

Figure 2 (A) H\&E, 10x: Epidermal atrophy with lichenoid damage, dermis showing top heavy confluent and bottom discrete granulomatous infiltrate with multiple well-formed epitheloid granulomas without central caseation necrosis. (B) H\&E, 40x: multinucleate Langhans giant cells with lichenoid damage of overlying epidermis.

\section{Learning points}

- A high index of suspicion with histopathological examination helps in arriving at a diagnosis of lupus vulgaris.

- Family history of lupus vulgaris may be present in high endemic area.

- Treatment is with standard antitubercular treatment.

Contributors Each author has contributed sufficiently. $\mathrm{KA}$ and $\mathrm{AB}$ : design, preparation of the manuscript and literature search. AD and NH : preparation, revision and submission of the manuscript and guidance.

Funding The authors have not declared a specific grant for this research from any funding agency in the public, commercial or not-for-profit sectors.

Competing interests None declared.

Patient consent for publication Obtained.

Provenance and peer review Not commissioned; externally peer reviewed.

\section{ORCID iD}

Neirita Hazarika http://orcid.org/0000-0003-4768-2857

\section{REFERENCES}

1 Sethuraman G, Ramesh V, Ramam M, et al. Skin tuberculosis in children: learning from India. Dermatol Clin 2008:26:285-94.

2 Sethi A. Tuberculosis and Infections with Atypical Mycobacteria. In: Kang S, Amagai M, Bruckner A, et al, eds. Fitzpatrick's dermatology. 9th ed. New York: McGraw-Hill, 2019: 2858-66.

3 Yates VM. Mycobacterial infection. In: Burns T, Breathnach S, Cox N, et al, eds. Rook's Textbook of Dermatology. 8th ed. Oxford: Blackwell Science Ltd, 2010: 16-19.

4 Saritha M, Parveen BA, Anandan V, et al. Atypical forms of lupus vulgaris - a case series. Int I Dermatol 2009:48:150-3.

5 Sehcal VN, Wagh SA. Cutaneous tuberculosis. Int I Dermatol 1990;29:237-52.

6 Micali G, Lacarrubba F, Massimino D, et al. Dermatoscopy: alternative uses in daily clinical practice. J Am Acad Dermatol 2011;64:1135-46.

7 Arya S, Kushwaha R, Bunkar M, et al. Extensive lupus vulgaris: a variant of extrapulmonary tuberculosis. Indian J Paediatr Dermatol 2016;17:161-3.

8 Pai VV, Naveen KN, Athanikar SB, et al. A clinico-histopathological study of lupus vulgaris: a 3 year experience at a tertiary care centre. Indian Dermatol Online J 2014; 5:461

Copyright 2021 BMJ Publishing Group. All rights reserved. For permission to reuse any of this content visit

https://www.bmj.com/company/products-services/rights-and-licensing/permissions/

BMJ Case Report Fellows may re-use this article for personal use and teaching without any further permission.

Become a Fellow of BMJ Case Reports today and you can:

- Submit as many cases as you like

- Enjoy fast sympathetic peer review and rapid publication of accepted articles

- Access all the published articles

Re-use any of the published material for personal use and teaching without further permission

Customer Service

If you have any further queries about your subscription, please contact our customer services team on +44 (0) 2071111105 or via email at support@bmj.com.

Visit casereports.bmj.com for more articles like this and to become a Fellow 